\title{
Fermentation technologies for the production of exopolysaccharide- synthesizing Lactobacillus rhamnosus concentrated cultures
}

\author{
Claude P. Champagne* \\ Food Research and Development Center \\ Agriculture and Agri-Food Canada \\ 3600 Casavant \\ St. Hyacinthe, QC \\ J2S 8E3 Canada \\ Tel:450 7731105 \\ Fax: 4507738461 \\ E-mail: ChampagneC@agr.gc.ca \\ Nancy J. Gardner \\ Food Research and Development Center \\ Agriculture and Agri-Food Canada \\ 3600 Casavant \\ St. Hyacinthe, QC \\ J2S 8E3 Canada \\ Christophe Lacroix \\ Laboratory of Food Biotechnology \\ Institute of Food Science and Nutrition \\ Schmelzbergstrasse 7 \\ ETH Zurich LFV C 20 \\ CH-8092 Zürich, Switzerland
}

Financial support: This work was carried out within the Research Network on Lactic Acid Bacteria, supported by the Natural Sciences and Engineering Research Council of Canada, Agriculture and Agri-food Canada, Novalait Inc., The Dairy Farmers of Canada and Rosell-Lallemand Inc.

Keywords: alginate beads, fed-batch culture, temperature.

Abbreviations: AS: automated spectrophotometry
CFU: colony forming units
CRV: capillary relative viscosities
EPS: exopolysaccharide
ICT: immobilized cell technology
LAB: lactic acid bacteria
MMRS: modified-MRS
OD: optical density
SEM: Standard error of the means
WP: whey permeate

The exopolysaccharide (EPS)-producing cultures such as Lactobacillus rhamnosus RW-9595M present a challenge for the culture producers because the high viscosity of the fermented growth medium makes it difficult to recover the cells by centrifugation or filtration. This study examined four approaches to reduce viscosity of the medium while producing high cell densities: incubation temperature, extended incubation in the stationary growth phase, production in alginate gel beads and fed-batch fermentation technology. Automated spectrophotometry (AS) was used to study the effects of temperature, $\mathrm{pH}$ and lactate level on growth of the strain. In AS assays, there was no significant difference in final maximal biomass production at temperatures ranging between $34^{\circ} \mathrm{C}$ to $44^{\circ} \mathrm{C}$, but lower yields were noted at $46^{\circ} \mathrm{C}$. A $\mathrm{pH}$ below 6.0 and a lactate concentration higher than $4 \%$ almost completely prevented growth. Under batch fermentation conditions, the viscosity of the medium obtained at $37^{\circ} \mathrm{C}$ was two fold higher than for $44^{\circ} \mathrm{C}$. For cultures produced at $37^{\circ} \mathrm{C}$, centrifugation at $10000 \mathrm{~g}$ during 5 min did not allow complete recovery of cells, in contrast to cultures grown at $44^{\circ} \mathrm{C}$. An extended period of incubation ( 5 hrs) in the stationary growth phase did not reduce the final viscosity of the growth medium. For similar biomass levels, the glucose-based fed-batch fermentation allowed a $\mathbf{4 0 \%}$ reduction in viscosity of the fermented medium in comparison to traditional batch

*Corresponding author 
cultures. High-density cell populations ( $\left.3 \times 10^{10} \mathrm{CFU} / \mathrm{g}\right)$ were obtained when $L$. rhamnosus $\mathrm{RW}-9595 \mathrm{M}$ was grown in alginate beads. However, overall biomass yields in the immobilized cell bioreactor were half of those obtained in free-cell fermentations. Therefore three methods of producing concentrated EPSproducing cultures are proposed.

Exopolysaccharide (EPS)-producing lactic acid bacteria (LAB) are of interest to the food industry because they can improve the texture of yoghurts (De Vuyst and Degeest, 1999; De Vuyst et al. 2001), decrease the risk of syneresis and improve yields in cheeses (Broadbent et al. 2001). In addition to their technological benefits, LAB EPS have been recognized to have antitumoral, antiulcer and blood cholesterol lowering activities, as well as the ability to enhance the immune system (Chabot et al. 2001; RuasMadiedo et al. 2002). Therefore EPS-producing strains are of commercial value for both their technological and putative probiotic properties.

In order to supply cultures directly to consumers or to the food industry, manufacturers must propagate the strains in appropriate media, recover the cells and stabilize cell concentrates by freezing or drying. With high EPS producing bacteria, such as Lactobacillus rhamnosus RW9595M (Macedo et al. 2002; Bergmaier et al. 2003), cell recovery presents a challenge for manufacturers because viscosity of the fermented medium could hinder centrifugation or filtration operations. There is therefore a need to develop fermentation technologies which can generate high biomass yields, while keeping the viscosity at a level which would enable easy recovery of the cells from the fermented broth.

A balance between carbon and nitrogen sources is necessary to obtain a high EPS concentration (De Vuyst and Degeest, 1999), but other factors such as growth temperature, $\mathrm{pH}$ and agitation affect EPS production (Gamar-Nourani et al. 1998). High incubation temperatures have been shown to reduce EPS production by lactobacilli (Grobben et al. 1995; Mozzi et al. 1996b), but it is unknown if the viscosity reduction is sufficient to enable easy recovery of cells. Fed-batch fermentation with high carbohydrate levels was successful in enhancing EPS production (Cheirsilp et al. 2003) but is it unknown if a reverse strategy (i.e. fed-batch with low carbohydrate level) could be used to generate a fermented medium with high cell concentration and low-viscosity.

In addition to the traditional concentrated starter technology, immobilized cell technology (ICT) has been proposed for the production of bacterial concentrates (Doleyres and Lacroix, 2005). Although the production of concentrates in alginate beads has the advantage of eliminating the need for a concentration step, the EPS yields are sometimes lower (Champagne et al. 1993) and some strains are adversely affected by entrapment in alginate gels (Lamboley et al. 2003). No data are available on the ICT production of EPS-producing strains of $L$. rhamnosus.

The objective of the present study was to examine four methods for the production of high bacterial populations while controlling viscosity of the medium: high incubation temperatures, extended incubation on the stationary growth phase (SGF), fed-batch fermentations and biomass production in alginate beads.

\section{MATERIALS AND METHODS}

\section{Cultures}

Stock cultures of L. rhamnosus RW-9595M were prepared by mixing a fresh MRS-grown culture with sterile rehydrated skim milk $(20 \% \mathrm{w} / \mathrm{w})$ and sterile glycerol $(20 \%$ $\mathrm{w} / \mathrm{w}$ ) in a 1:2:2 ratio, and placing $1 \mathrm{ml}$ fraction in Cryovials (Nalge, Rochester, USA). The cell suspensions were then frozen and kept at $-70^{\circ} \mathrm{C}$ until used. The inocula for fermentations were prepared by adding $1 \mathrm{ml}$ of a thawed stock culture to $50 \mathrm{ml}$ MRS broth and incubating at $37^{\circ} \mathrm{C}$ until a pH of 4.5-4.8 was reached (typically after $6.5 \mathrm{hrs}$ ). For spectrophotometric assays, $1 \mathrm{ml}$ of MRS-grown culture was added to $9 \mathrm{ml}$ of $0.01 \%(\mathrm{w} / \mathrm{v})$ sterile peptone water (Difco, Detroit, USA) and this cell suspension served to inoculate the wells in the microplates. Forthe preparation of the alginate-entrapped culture, a fresh MRS-grown culture $(15 \mathrm{ml})$ was mixed with $60 \mathrm{ml}$ of a sterile $2 \%(\mathrm{w} / \mathrm{v})$ alginate solution (Sobalg 126, Grindsted, Denmark), and the cell suspension was added dropwise to $200 \mathrm{ml}$ of a $0.2 \mathrm{M} \mathrm{CaCl}_{2}$ solution. Beads with approximately $2 \mathrm{~mm}$ diameter were left in the $\mathrm{CaCl}_{2}$ solution for 30 min to allow hardening and then recovered in a sterile Buchner filter. Approximately 62 $\mathrm{g}$ of beads were obtained.

\section{Spectrophotometric analyses for the determination of growth parameters}

Since Method 1 was based on the use of over-optimal growth temperatures, it was necessary to ascertain the optimum growth temperature for this particular strain. With respect to Method 4, the strategy required prior knowledge of the amount of sugar needed to carry out an extended fermentation. Thus, preliminary assays using automated spectrophotometry (AS) were carried out to ascertain the conditions of $\mathrm{pH}$, temperature and maximum lactate concentration that were to be subsequently used for fermentations. The AS assays were not conducted on the modified-MRS (MMRS) or whey media used for fermentations because such media generate biomass levels which are too high. Indeed, in AS assays it is recommended to limit the growth of the culture to optical density (OD) values under 1.0. Thus AS assays were conducted in the basal medium described by Morishita et al. (1981) for lactobacilli. It had the following composition per liter: $70 \mathrm{~g}$ lactose, 3 g KH2PO 4 , $3 \mathrm{~g} \mathrm{~K}_{2} \mathrm{HPO}_{4}, 1 \mathrm{~g}$ Tween 80 and $1 \mathrm{ml}$ of a concentrated stock solution of the following elements to a final concentration per litre of: $0.05 \mathrm{~g} \mathrm{MnSO}_{4} \cdot 7 \mathrm{H}_{2} \mathrm{O}$, 


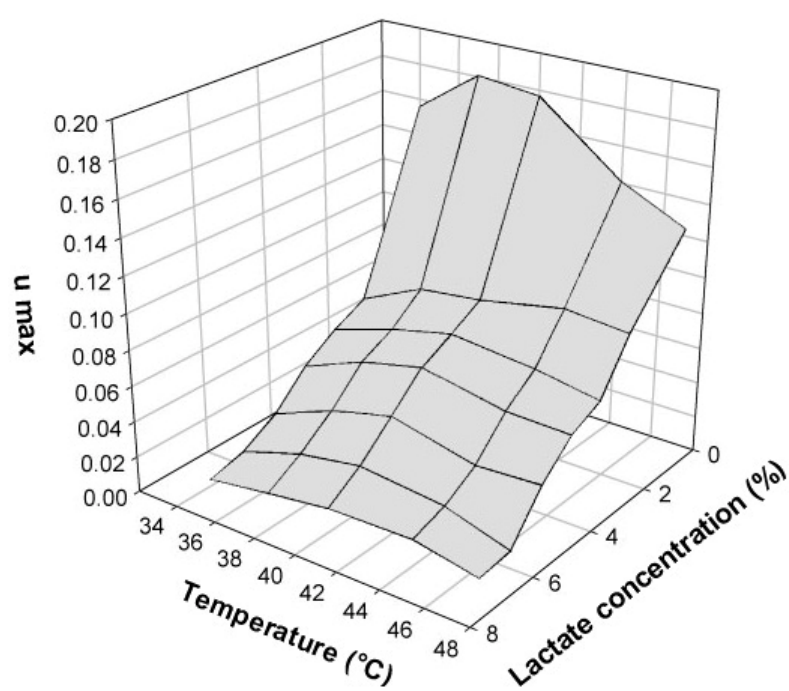

Figure 1. Effect of growth temperature and initial lactate concentration on maximal optical density (OD max) of Lactobacillus rhamnosus RW-9595 $\mathrm{M}$ in the medium used in AS assays.

$0.5 \mathrm{~g} \mathrm{MgSO}_{4} \cdot 7 \mathrm{H}_{2} \mathrm{O}, 6 \mathrm{~g}$ sodium acetate, $1 \mathrm{~g}$ ammonium citrate, $0.02 \mathrm{~g} \mathrm{FeSO} \cdot 7 \mathrm{H}_{2} \mathrm{O}$. Then, $100 \mathrm{ml}$ of a stock solution of amino acids composed per liter of $: 1 \mathrm{~g} \mathrm{~L}$ arginine, 2 g L-aspartic acid, 2 g L-cysteine, 2 g L-glutamic acid, $1 \mathrm{~g}$ L-leucine, $1 \mathrm{~g}$ L-isoleucine, $1 \mathrm{~g}$ L-lysine, $1 \mathrm{~g} \mathrm{~L}$ methionine, $1 \mathrm{~g}$ L-phenylalanine, $1 \mathrm{~g}$ L-serine, $1 \mathrm{~g}$ Lthreonine, $1 \mathrm{~g}$ L-tryptophan, $1 \mathrm{~g}$ L-tyrosine, $1 \mathrm{~g}$ L-valine, were added. For the $\mathrm{pH}$ assays, the $\mathrm{pH}$ was adjusted to 5.1, $5.4,5.7,6.0$ and 6.3 with $\mathrm{HCl} 3 \mathrm{M}$ prior to sterilisation at $121^{\circ} \mathrm{C}$ for $5 \mathrm{~min}$. This was the actual holding time of the medium at $121^{\circ} \mathrm{C}$. The holding time was initiated when the medium had reached $121^{\circ} \mathrm{C}$ and not when the sterilization chamber had attained the temperature, which is much earlier. This was enabled by placing a temperature probe in the medium during sterilization. After cooling, $1 \mathrm{ml}$ per liter of a filter sterilized stock solution of vitamins (per litre composed of $0.1 \mathrm{~g}$ folic acid, $1 \mathrm{~g}$ nicotinic acid, $1 \mathrm{~g}$ pantothenic acid, $2 \mathrm{~g}$ pyridoxal and $1 \mathrm{~g}$ riboflavine) completed the medium formulation. For the lactate concentration assays, a solution of $60 \%$ sodium lactate (Fisher, Montréal, QC, Canada) was added to the base medium to obtain a final lactate concentration of $0,2,3,4$, 5,6 and $7 \%(\mathrm{w} / \mathrm{v})$. The $\mathrm{pH}$ was adjusted to 6.0 prior to sterilisation.

$200 \mu \mathrm{l}$ of sterile media were then dispensed in wells (Polystyrene sterile 96 well plates, Costar, NY, USA) and inoculated with $10 \mu \mathrm{l}$ of fresh inoculum. Noninoculated wells were also used to determine the baseline of each condition. The plates were then placed into a Powerwave (KC-4, Bio-Tek, VT, USA) incubation chamber for which shaking frequency (10 sec every $15 \mathrm{~min}$ ), intensity (low), wavelength $(600 \mathrm{~nm})$ and OD reading frequency (every 15 min) were kept constant for the following temperatures: 34 ,
$37,40,44$ or $47^{\circ} \mathrm{C}$. In each assay, triplicate wells for each condition were performed and mean values were used to calculate the maximal optical density (OD max) and the maximal growth rate $(\mu \max )$ for the given assay. Three independent replications were carried out.

\section{Method 1. Use of over-optimal growth temperatures}

In assays with Method 1, the growth medium was selected to generate the highest possible biomass and, hence, a high EPS level. This was done to simulate industrial conditions which are designed to attain high biomass, as well as to generate the highest possible viscosity in order to test the value of our hypothesis. The medium used to evaluate the effect of temperature on cell growth and viscosity was formulated with ingredients of commercial sources recognized as enabling very good growth of strain RW9595M as well as high EPS levels (Macedo et al. 2002). The whey permeate (WP) based medium was prepared by first adding $78 \mathrm{~g}$ WP powder (Saputo, Montréal) in $800 \mathrm{ml}$ of distilled water. The $\mathrm{pH}$ was adjusted to 5.0 with $\mathrm{HCl} 3 \mathrm{M}$ prior to heating $\left(121^{\circ} \mathrm{C}, 10 \mathrm{~min}\right)$. After cooling, the solution was filtered on a $8 \mu \mathrm{m}$ Whatman (MI, USA) \#2 paper to remove heat-formed precipitates. The $\mathrm{pH}$ was then readjusted to 5.0 and the following solution added per litre: $2.5 \mathrm{ml}$ Tween $80,3 \mathrm{~g} \mathrm{KH} \mathrm{KO}_{4}, 3 \mathrm{~g} \mathrm{~K}_{2} \mathrm{HPO}_{4}, 100 \mathrm{ml}$ of the stock solution of mineral salts, $100 \mathrm{ml}$ of amino acids as described above and $5 \mathrm{~g}$ of yeast extracts previously ultrafiltered at $10 \mathrm{kDa}$ to remove polysaccharides (Champagne et al. 1999). The medium was sterilised again $\left(121^{\circ} \mathrm{C}, 1 \mathrm{~min}\right)$, cooled to room temperature and $1 \mathrm{ml}$ of the stock solution of vitamins was added per litre of medium.

Batch cultures were conducted in three $2.5 \mathrm{~L}$ fermentors (New Brunswick Scientific Co., models BioFlo III and BioFlo 3000, Edison, NJ, USA) inoculated at $0.6 \%(\mathrm{v} / \mathrm{v})$ with a fresh sub-culture at a controlled temperature of 37 , 42 or $44^{\circ} \mathrm{C}$, with agitation set at $100 \mathrm{rpm}$ and $\mathrm{pH}$ controlled at 6.0 by addition of a mixture of $\mathrm{KOH} 6 \mathrm{~N}$ and $\mathrm{NH}_{4} \mathrm{OH} 6 \mathrm{~N}$ prepared in 5:1 ratio. Fermentations were carried out until stabilisation of the OD. Samples were aseptically withdrawn when the SGP had been reached (between 11.5 and $14.2 \mathrm{hrs}$; Table 1) to determine bacterial populations, lactose consumption and lactic acid production, as well as relative viscosity of the culture broth.

\section{Method 2. Over-incubation of the culture in the SGP}

In Method 1, samples were taken at the beginning of the SGP. For Method 2, the incubation of the same media was simply extended at 42 or $44^{\circ} \mathrm{C}$ for $5 \mathrm{hrs}$ in the SGP. Samples were then taken again to ascertain the effect of this extended incubation on viable counts, viscosity and OD before and after centrifugation. Sampling times varied between 16.5 and $17.8 \mathrm{hrs}$ (Table 1) as a function of the time at which the SGP had been reached. 
Table 1. Effect of fermentation temperature and extended incubation in the stationary growth phase (5 hrs) on biomass levels of Lactobacillus rhamnosus RW-9595M, medium CRV and the subsequent removal of cells by centrifugation.

\begin{tabular}{|c|c|c|c|c|c|c|c|c|}
\hline \multicolumn{2}{|c|}{ Fermentation } & \multirow{2}{*}{$\begin{array}{l}\text { Fermentation } \\
\text { time (hr) }\end{array}$} & \multirow{2}{*}{$\begin{array}{l}\text { Population } \\
\text { (CFU/mI) }\end{array}$} & \multirow{2}{*}{$\begin{array}{l}\text { Cells per } \\
\text { chain }^{1}\end{array}$} & \multirow{2}{*}{ CRV } & \multicolumn{3}{|c|}{ OD } \\
\hline Temperature & Growth phase & & & & & $\begin{array}{c}\text { Before } \\
\text { CF }^{2}\end{array}$ & $\begin{array}{c}\text { After CF } \\
4000 \mathrm{~g}\end{array}$ & $\begin{array}{l}\text { After CF } \\
10000 \mathrm{~g}\end{array}$ \\
\hline $37^{\circ} \mathrm{C}$ & Beginning stationary & $14.2(0.4)$ & $9.3(0.9) \times 10^{9}$ & $1.3(0.1)$ & $4.81(0.29)$ & $11.1(0.1)$ & $5.7(0.1)$ & $5.8(0.1)$ \\
\hline $42^{\circ} \mathrm{C}$ & Beginning stationary & $12.8(0.3)$ & $7.2(1.3) \times 10^{9}$ & $1.7(0.1)$ & $2.66(0.27)$ & $11.8(0.3)$ & $5.9(0.1)$ & $1.7(1.1)$ \\
\hline $42^{\circ} \mathrm{C}$ & 5 hrs in stationary & $17.8(0.3)$ & $5.7(0.6) \times 10^{9}$ & $1.8(0.2)$ & $2.97(0.32)$ & $11.4(0.3)$ & $5.8(0.1)$ & $2.4(1.0)$ \\
\hline $44^{\circ} \mathrm{C}$ & Beginning stationary & $11.5(0.6)$ & $6.3(1.1) \times 10^{9}$ & $1.5(0.3)$ & $2.20(0.06)$ & $12.0(0.2)$ & $5.8(0.1)$ & $0.1(0.1)$ \\
\hline $44^{\circ} \mathrm{C}$ & $5 \mathrm{hrs}$ in stationary & $16.5(0.6)$ & $5.4(0.6) \times 10^{9}$ & $2.0(0.4)$ & $2.25(0.04)$ & $11.7(0.3)$ & $5.7(0.1)$ & $0.1(0.1)$ \\
\hline
\end{tabular}

\footnotetext{
${ }^{1}$ Average number of cells per chain

${ }^{2} \mathrm{CF}$ : Centrifugation

Values in brackets represent SEM obtained from three independent assays.
}

\section{Method 3. Production in alginate beads}

Assays with Method 3 and Method 4 were done simultaneously in order to compare biomass levels of the three fermentation technologies (free, immobilized and fedbatch). However, the WP medium could not be used for Method 4, because it was necessary to have a low level of carbohydrate at the beginning of the fermentation (low $\mathrm{C} / \mathrm{N}$ ratio), which the WP media did not enable. It was therefore necessary to use a synthetic medium where the carbohydrate could be added separately from the other ingredients. A MMRS was thus formulated for its carbohydrate-defined composition as opposed to the WPbased medium where the lactose content cannot be varied without changing the other solids content. The MMRS was prepared as follows (per litre of medium): $10 \mathrm{~g}$ tryptone (N1, Organotechnie, TechniScience Montreal QC Canada), $10 \mathrm{~g}$ beef extract, $5 \mathrm{~g}$ yeast extract (FNI 100, Lallemand, Montreal QC Canada), $1 \mathrm{~g}$ Tween 80, $1 \mathrm{~g}$ ammonium citrate, $2 \mathrm{~g}$ sodium acetate, $0.1 \mathrm{MgSO}_{4}, 0.05 \mathrm{~g} \mathrm{MnSO}_{4}, 1 \mathrm{~g}$ $\mathrm{K}_{2} \mathrm{HPO}_{4}$. The medium $\left(1.5\right.$ litre) was sterilized at $121^{\circ} \mathrm{C}$ for $10 \mathrm{~min}$ (actual temperature probe-controlled holding time at $\left.121^{\circ} \mathrm{C}\right)$. Solutions with $60 \%$ glucose (w/v) or $50 \% \mathrm{CaCl}_{2}$ $(\mathrm{w} / \mathrm{v})$ were prepared separately, and sterilized at $121^{\circ} \mathrm{C}$ for $10 \mathrm{~min}$. In the control (batch) fermentation with free cells, the fermenter jar was sterilized at $121^{\circ} \mathrm{C}$ for $30 \mathrm{~min}$ and sterile MMRS was added. The MMRS base (1.5 litre) was supplemented with $180 \mathrm{ml}$ of the $60 \%$ glucose solution and $50 \mathrm{ml}$ of $50 \% \mathrm{CaCl}_{2}$, for final concentrations of $0.1 \mathrm{M}$ of $\mathrm{CaCl}_{2}$ and $60 \mathrm{~g} / \mathrm{l}$ glucose. This medium, with all the glucose added at the beginning of the fermentation, was used for the free cell control as well as for the alginate bead-based ICT method. The medium was inoculated with $15 \mathrm{ml}$ of an MRS-grown culture mixed with $47 \mathrm{ml}$ of $0.2 \mathrm{M} \mathrm{CaCl}_{2}$.

This inoculation procedure was carried out in order to compare this treatment with batch fermentations performed with alginate beads, where the same volume of fresh culture was entrapped in $62 \mathrm{~g}$ of beads recovered from the $0.2 \mathrm{M}$ $\mathrm{CaCl}_{2}$ solution. Bead samples were taken for analyses at the beginning of the SGP (when acidification has stopped).

With alginate beads, fermentations inoculated with $62 \mathrm{~g}$ of the freshly prepared alginate particles were carried out. The medium was supplemented with $50 \mathrm{~mL}$ of $50 \% \mathrm{CaCl}_{2}$ to maintain bead integrity. The fermentation and samplings were carried out as for the free cell batch fermentations. Viable populations in the beads as well as in the medium, capillary relative viscosities (CRV) of the medium and sugar/acid concentrations were analysed.

\section{Method 4. Use of fed-batch technology}

In fed-batch fermentations, the MMRS base (1.5 litre) was supplemented with $50 \mathrm{ml}$ of the concentrated $(50 \%) \mathrm{CaCl}_{2}$ solution and only $30 \mathrm{ml}$ of $60 \%$ glucose solution for a starting concentration of $1.2 \%$. Inoculation and fermentation were conducted as described for the free-cell control until acid production stopped, indicating complete assimilation of the initial glucose. Injection of sterile $60 \%$ glucose at a $30 \mathrm{ml} / \mathrm{h}$ rate was then carried out over $5 \mathrm{hrs}$. 
Samples were taken when the fed batch process was initiated, as well as at every $\mathrm{hr}$ thereafter. Viable populations, CRV of the medium and sugar/acid concentrations were analysed.

All fermentations (batch or fed batch) were carried out on 2.5 litre New-Brunswick Scientific BioFlo 3000 or BioFlo III units. The temperature was maintained at $42^{\circ} \mathrm{C}$, agitation set at $100 \mathrm{rpm}$, and $\mathrm{pH}$ kept at 6.0 by addition of a mixture of $\mathrm{KOH} 6 \mathrm{~N}$ and $\mathrm{NH}_{4} \mathrm{OH} 6 \mathrm{~N}$ prepared in 5:1 ratio.

\section{Microbial analyses}

The viable population in the medium (free cells) was determined by plating appropriate dilutions of the cultures on MRS agar, and incubating at $37^{\circ} \mathrm{C}$ for $48 \mathrm{hrs}$. To break cell chains, the cell suspension of the first dilution $(1 \mathrm{ml}$ of culture in $99 \mathrm{ml}$ of $0.1 \%$ peptone) was treated with a highspeed $(25000 \mathrm{rpm})$ homogenization probe (Omni International, Marietta GA USA) during $1 \mathrm{~min}$. The viable population in the beads was determined by dissolving approximately $0.5 \mathrm{~g}$ of beads in $99 \mathrm{ml}$ of $1 \%$ sodium citrate, and plating the subsequent dilutions in $0.1 \%$ peptone as described above. The first dilution bottle was then also treated by the high-speed homogenization to break cell chains. Since lactobacilli grow in cell chains of various lengths, colony forming units (CFU) counts may underestimate of the actual population values. Indeed, if chains have, on the average, 3 cells per chain, then the CFU counts only register $33 \%$ of the actual cell population. Therefore, in order to try to accurately present the true number of cells in the sample, we examined culture smears at a $1000 \mathrm{X}$ enlargement ocular and tried to assess the average number of cells per chain. To provide total cell counts, we then simply multiply this "average number of cells per chain" with the CFU count. The cells were coloured with methylene blue prior to examination.

\section{HPLC analyses}

Substrates and products were analysed by HPLC using a Waters (Mississauga, Canada) system coupled to Millennium software. Samples were centrifuged and filtered on a HVLP 0.22 : membrane prior separation on a Aminex HPX 87H column (BioRad, Mississauga, Canada) heated at $45^{\circ} \mathrm{C}$. Detection was done with a refractive index monitor (model 410 , Waters) controlled at $40^{\circ} \mathrm{C}$ and a photodiode array detector model 996 (Waters). The mobile phase was made of $\mathrm{H}_{2} \mathrm{SO}_{4} 0.008 \mathrm{~N}$ and circulated at 0.4 $\mathrm{ml} / \mathrm{min}$.

\section{OD measurements in the fermented media}

Growth media were centrifuged at $4000 \mathrm{~g}$ or $10000 \mathrm{~g}$ during $5 \mathrm{~min}$ at $4^{\circ} \mathrm{C}$ and samples analysed for OD before and after (supernatants) centrifugation to estimate the remaining biomass after centrifugation. Since the relationship between biomass and OD is not linear with OD values above 1.0, samples having high OD needed to be

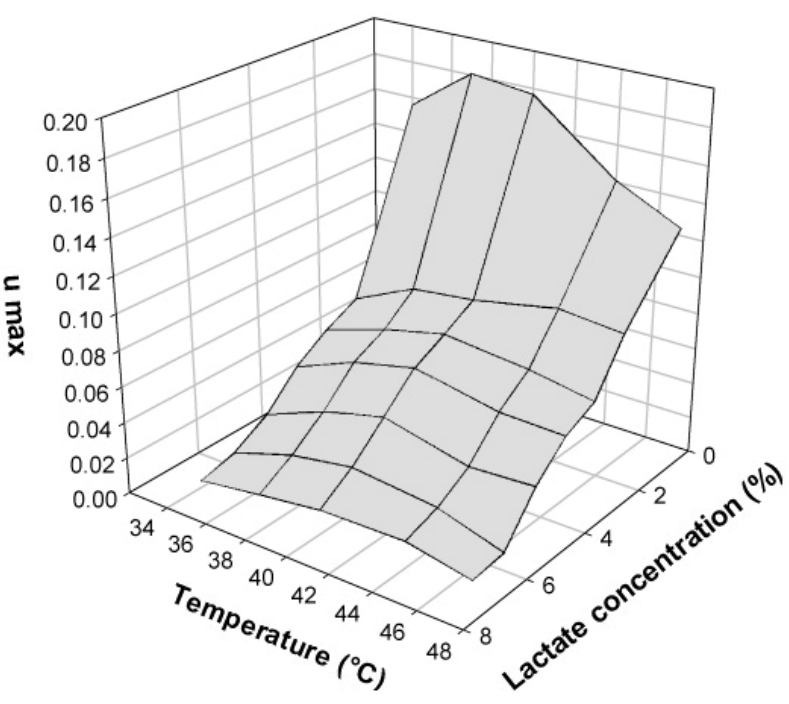

Figure 2. Effect of growth temperature and initial lactate concentration on maximal growth rate $(\mu \max )$ of Lactobacillus rhamnosus RW-9595M.

diluted prior to reading. The OD readings were carried out by placing the sample (diluted or not) in a $1 \mathrm{ml}$ cuvette, which was scanned using a Beckman, DU7400 (CA, USA) spectrophotometer. The final OD was obtained by multiplying the diluted OD by the dilution factor when necessary.

\section{Capillary relative viscosity determination}

$15 \mathrm{ml}$ of broth of culture or supernatant were introduced in a capillary Ubbelohde 1B unit placed into a water bath with a control temperature at $25^{\circ} \mathrm{C}$ for $10 \mathrm{~min}$. With the capillary unit used in these assay, $15 \mathrm{ml}$ of water typically required $19 \mathrm{sec}$ to flow out of the system. The CRV reported are the ratio between the time (in sec) required by the experimental sample to flow out of the viscometer and that of water at the same experimental conditions. Reported data are the mean of triplicate analysis.

\section{Statistical analyses}

Data are the average of three independent assays. CFU values were converted into their corresponding $\log _{10}$ numbers and ANOVA were then carried out using the Student-Newman-Keuls procedure with Instat 3.0 software (GraphPad, San Diego, USA). The $\alpha=0.05$ level was used to ascertain the statistical significance of the differences. Paired $t$ tests were used to evaluate the effect of extended incubations on viability drops at each incubation temperature (Method 2). Standard Error of the Means (SEM) values are presented in brackets in the tables.

\section{RESULTS AND DISCUSSION}

Many studies show that EPS production in lactobacilli is strongly linked to biomass levels (De Vuyst et al. 1998; 
Torino et al. 2000). Although viscosity does not always correlate with EPS production (Shihata and Shah, 2002; Ruas-Madiedo et al. 2005) for L. rhamnosus RW-9595M, there is a correlation between EPS concentration in the medium and CRV values (Macedo et al. 2002). Then, by keeping the biomass yield of a culture at a low level, one could achieve the goal of having a low-viscosity fermented medium. However, from a starter manufacturer point of view, high biomass productions are desirable, which eventually lead to high medium viscosity. Attempts were thus made to find fermentation parameters which would enable high biomass as well as low EPS production.

\section{Selection of temperature, lactate concentration and $\mathrm{pH}$ parameters for fermentation assays}

AS evaluates growth from continuous OD readings, and media must be specially formulated for these assays in order to limit the growth in an OD range in which OD and biomass are linearly correlated. AS enabled the evaluation of the combined effects of lactate concentration, $\mathrm{pH}$ and temperature on the growth of L. rhamnosus RW-9595M.

ANOVA on OD max data from media at $\mathrm{pH} 6.0$ with no added lactate $(0 \%$ lactate, Figure 1$)$ revealed that there was no significant $(\mathrm{P}>0.05)$ effect of incubation temperatures between 34 and $44^{\circ} \mathrm{C}$ on OD max values, but that $46^{\circ} \mathrm{C}$ was detrimental to biomass production.

Data for $\mu$ max differed from that of OD max. At $\mathrm{pH} 6.0$ and without added lactate $(0 \%$ lactate, Figure 2$)$, the ANOVA revealed that the highest growth rates $(\mu$ max values) were obtained between 34 and $40^{\circ} \mathrm{C}$ and decreased significantly at higher temperatures (Figure 2). These data enabled the selection of $37^{\circ} \mathrm{C}, 42^{\circ} \mathrm{C}$ and $44^{\circ} \mathrm{C}$ for fermentation assays on the effect of temperature (Method 1). Incubation at $46^{\circ} \mathrm{C}$ clearly affected both biomass yield and growth rate and was unacceptable. Although the growth rate at $44^{\circ} \mathrm{C}$ was lower that at 40 or $37^{\circ} \mathrm{C}$ (Figure 2) the biomass levels were similar for the three temperatures. Thus, $44^{\circ} \mathrm{C}$ was selected as the over-optimal growth temperature for the assays in Method 1.

When $\mathrm{pH}$ of the media were adjusted below 6.0, the ANOVA analysis of $\mu$ max data in media with no added lactate revealed significantly lower values (data not shown). These data served to select a $\mathrm{pH}$ value of 6.0 for subsequent biomass productions in fermenters. These results are in line with those of Mozzi et al. (1996a) who reported lower populations under $\mathrm{pH} 6$.

Lactate concentrations higher than $4 \%$ substantially decreased the growth of L. rhamnosus RW-9595M, and negligible growth was noted in media adjusted at $\mathrm{pH} 6.0$ having 6\% lactate (Figure 1 and Figure 2). These AS results thus enabled the selection of $6 \%$ of glucose for the fedbatch assays (Method 4), in order to generate the $4 \%$ lactate level judged to be critically detrimental to biomass and growth rate levels. Indeed, preliminary data with this strain (not shown) suggested a conversion level of glucose to lactate of approximately $75 \%$ (Table 2 ).

Under $\mathrm{pH}$ control, lactate accumulation can generate growth inhibition (Cachon and Diviès, 1993), but the inhibitory level varies between strains, species, $\mathrm{pH}$ and temperature (Houtsma et al. 1996). The AS data was in line with the literature, showing lactobacilli to be more tolerant to lactate than are lactococci (Stieber et al. 1977; Cachon and Diviès, 1993).

\section{Method 1. Effect of temperature on biomass and viscosity of the fermented media}

During $\mathrm{pH}$-controlled batch productions in the whey-based medium, fermentation times to reach the SGP were longer for temperatures below $42^{\circ} \mathrm{C}$ (Table 1), which was in line with the AS data (Figure 1 and Figure 2). The highest $\mathrm{CFU} / \mathrm{ml}$ value was obtained at $37^{\circ} \mathrm{C}$ (Table 1) but the ANOVA on data at the beginning of the SGP showed that the difference with those at 42 and $44^{\circ} \mathrm{C}$ was not judged to be significant $(\mathrm{P}>0.05)$ when the average number of cells per chain value was taken into account and CFU values were multiplied by these values (Table 1) to ascertain the total cell counts. The populations obtained were in accordance with those reported by Bergmaier et al. (2003) on WP medium after $18 \mathrm{hrs}$ of fermentation for this $L$. rhamnosus $\mathrm{RW}-9595 \mathrm{M}$ strain.

$\mathrm{CRV}$ of the media was 2 -fold higher at $37^{\circ} \mathrm{C}$ than at $42^{\circ} \mathrm{C}$ or $44^{\circ} \mathrm{C}$ (Table 1). These data are in agreement with many studies showing higher viscosities at sub-optimal growth temperatures (Gassem et al. 1995; Mozzi et al. 1995) as well as with those of Gamar-Nourani et al. (1997) who found lower EPS production by L. rhamnosus at high incubation temperatures. Under these conditions, because of the higher viscosity obtained at $37^{\circ} \mathrm{C}$, even a centrifugation at $10000 \mathrm{~g}$ for $5 \mathrm{~min}$ did not allow complete retrieval of the biomass from the growth medium (Table 1).

Complete retrieval of cells was not possible for any of the cultures when using a centrifugation force of $4000 \mathrm{~g}$ during $5 \mathrm{~min}$. However, at $10000 \mathrm{~g}$, the low viscosity of the culture grown at $44^{\circ} \mathrm{C}$ allowed complete separation of the bacteria from the medium. Therefore, this study was successful in showing that over-optimal incubation temperatures can be used to lower medium viscosity sufficiently to recover cells under certain centrifugation conditions. It remains to be determined to what extent this strategy can be used for other species. Indeed, with many thermophilic strains, EPS production (and hence viscosity) seems to be growthassociated (De Vuyst et al. 1998).

\section{Method 2. Extended incubation}

Since it was reported that EPS production (Pham et al. 2000) and CRV (Macedo et al. 2002) of L. rhamnosus cultures were at its highest at the beginning of the SGP and dropped steadily thereafter, an attempt was made to see if 
Table 2. Effect of fermentation technologies on the population of Lactobacillus rhamnosus RW-9595M, medium CRV and glucose/lactate levels in the fermented media.

\begin{tabular}{|c|c|c|c|c|}
\hline $\begin{array}{c}\text { Fermentation } \\
\text { technology }\end{array}$ & $\begin{array}{l}\text { Population } \\
\text { (CFU/ml or } / g)\end{array}$ & CRV & $\begin{array}{c}\text { Glucose } \\
\text { (g/l) }\end{array}$ & $\begin{array}{l}\text { Lactate } \\
\text { (g/l) }\end{array}$ \\
\hline Free cell control & $3.0(0.9) \times 10^{9}$ & $5.07(0.32)$ & 0 & $37.3(3.2)$ \\
\hline \multicolumn{5}{|l|}{ Immobilized cells } \\
\hline Beads & $3.0(1.5) \times 10^{10}$ & $4.41(0.92)$ & $0.4(0.03)$ & $38.7(2.6)$ \\
\hline Free cells outside beads & $1.1(2.4) \times 10^{9}$ & & & \\
\hline \multicolumn{5}{|l|}{ Fed batch } \\
\hline Beginning & $8.3(2.0) \times 10^{8}$ & $1.26(0.17)$ & 0 & $9.7(1.7)$ \\
\hline $1 \mathrm{hr}$ & $8.0(1.9) \times 10^{8}$ & $1.52(0.18)$ & $0.9(0.1)$ & $16.0(1.8)$ \\
\hline $2 \mathrm{hrs}$ & $2.0(0.9) \times 10^{9}$ & $1.60(0.30)$ & $2.5(0.6)$ & $21.6(3.0)$ \\
\hline $3 \mathrm{hrs}$ & $2.1(0.2) \times 10^{9}$ & $2.23(0.13)$ & $2.5(0.3)$ & $22.5(1.3)$ \\
\hline $4 \mathrm{hrs}$ & $2.6(0.4) \times 10^{9}$ & $2.50(0.42)$ & $5.6(0.4)$ & $33.4(4.2)$ \\
\hline $5 \mathrm{hrs}$ & $3.9(1.4) \times 10^{9}$ & $3.25(0.29)$ & $7.9(0.5)$ & $38.7(2.9)$ \\
\hline
\end{tabular}

Values in brackets represent SEM obtained from three independent assays.

this phenomenon could be used to enhance recovery of the cells by centrifugation. Unfortunately, the CRV of the fermented medium was not significantly reduced after $5 \mathrm{hrs}$ extended incubation in the SGP (Table 1). It was suggested that hydrolases activated by specific growth conditions caused degradation of the EPS (Pham et al. 2000), but our experimental conditions do not seem to have generated this EPS hydrolysis.

An apparent drop in viable counts of approximately $20 \%$ was noted during prolonged fermentation periods, but paired $t$ tests on population differences are not shown to be significant when total populations are calculated (multiplication of the CFU vales by the average number of cells per chain).

\section{Method 3. ICT}

In the ICT system, populations per $\mathrm{g}$ of beads in the MMRS were 10 times higher than for the free-cell control batch fermentations (Table 2). However, when the total yield of the bioreactor is considered, the total population from the beads represented only $40 \%$ of that obtained in free cells bioreactor. CRV values obtained for immobilized cells were slightly lower than for the free cells. Lactate concentrations for both treatments were similar.
The production of biomass by growing lactic cultures in alginate beads had previously been suggested (Champagne et al. 1992; Champagne et al. 1993), particularly for cultures which were sensitive to oxygen or centrifugation stresses. For EPS producers, the immobilization techniques may facilitate the recovery of the cells even in a viscous environment as they are entrapped in beads (Table 2) and this presents the main advantage. Thus, recovery of the beads could easily be carried out with a simple filtration unit. However, an important disadvantage with this technology was the lower biomass yields. A method to improve populations in beads, and reduced cell release into the medium, must be developed.

At $42^{\circ} \mathrm{C}$, the free cell control produced on MMRS (Table 2) yielded a lower total biomass than the one obtained from the supplemented WP (Table 1). On the other hand, the viscosities obtained with the MMRS medium with the free and immobilized cells were higher to the ones obtained in the supplemented WP at $42^{\circ} \mathrm{C}$.

\section{Method 4. Fed-batch technology}

During fed-batch cultures, the medium viscosity increased in parallel with the cell counts (Table 2). However, the final CRV of 3.25 was almost $40 \%$ lower than the viscosity obtained during control batch fermentation (Table 2) and 
for equal biomass levels. At the end of the culture, glucose concentrations were low $(0.4 \mathrm{~g} / \mathrm{l})$ and the lactate concentration was at $38.7 \mathrm{~g} / \mathrm{l}$ for both the immobilized and free cells.

The quantity of carbohydrates in the medium affects EPS yields (Prasher et al. 1997) and high initial carbohydrate levels tend to enhance final EPS levels (De Vuyst et al. 1998; Cheirsilp et al. 2003; Korakli et al. 2003). It was therefore our strategy to add glucose at a level allowing maximum growth, and to prevent an excess of carbohydrate which would result in enhanced EPS production, particularly in the fed-batch assays. As mentioned previously, a $6 \%$ glucose level was chosen using the AS data. As expected, lower CRV were obtained for the fed batch productions, during which glucose concentration was equal or lower than $12 \mathrm{~g} / \mathrm{l}$. However similar final lactate concentrations and populations as for the batch production were obtained. The excess of glucose at the end of the fed batch process indicates that the feeding rate of glucose should be lowered towards the end of the fermentation. Because a lower viscosity was obtained in the fed-batch MMRS cultures, compared to control batch fermentations, it can be expected that cell recovery by centrifugation at $10000 \mathrm{~g}$ would be improved with this strategy, as shown in Table 1 for other conditions yielding similar CRV.

The current formulation of MMRS is expensive and other formulations could be used commercially. If defined media are used, these data show that it would be useful to add all the nitrogen-based compounds (peptones, yeast extracts) at the beginning of the fermentation and add the carbohydrate under fed-batch.

\section{CONCLUDING REMARKS}

This study showed the effects of different culture conditions on growth of L. rhamnosus RW-9595M and on viscosity of fermented media. Lower viscosities and good growth were obtained by maintaining the growth temperature at $44^{\circ} \mathrm{C}$ and $\mathrm{pH}$ at 6.0 or by conducting the fermentation under a fed-batch process. Both methods could facilitate separation of the cells from the growth medium. Immobilization in alginate beads also enables the recovery of concentrated EPS-producing cultures, but the yields are lower than with free cells.

This study shows that many approaches are possible for the production of concentrated suspensions of valuable probiotic or starter EPS-producing cultures, which can be adapted to the equipment and media available or the strains involved.

\section{ACKNOWLEDGMENTS}

Gratitude is expressed to Ms. Cathy St-Laurent for technical assistance.

\section{REFERENCES}

BERGMAIER, D.; CHAMPAGNE, C.P. and LACROIX, C. Exopolysaccharide production during batch cultures with free and immobilized Lactobacillus rhamnosus RW9595M. Journal of Applied Microbiology, November 2003, vol. 95 , no. 5, p. 1049-1057.

BROADBENT, Jeffery R.; MCMAHON, Donald J.; OBERG, Craig J. and WELKER, Dennis L. Use of exopolysaccharide-producing cultures to improve the functionality of low fat cheese. International Dairy Journal, July 2001, vol. 11, no. 4-7, p. 433-439.

CACHON, R. and DIVIÈS, C. Modeling of growth and lactate fermentation by Lactococcus lactis ssp. lactis biovar. diacetylactis in batch culture. Applied Microbiology and Biotechnology, October 1993, vol. 40, no. 1, p. 28-33.

CHABOT, Silvie; YU, Han-Ling; DE LÉSÉLEUC, Louis; CLOUTIER, Denise; VAN CALSTEREN, Marie-Rose; LESSARD, Martin; ROY, Denis; LACROIX, Monique and OTH, Daniel. Exopolysaccharides from Lactobacillus rhamnosus RW-9595M stimulate TNF, IL-6 and IL-12 in human and mouse cultured immunocompetent cells and IFN- $\gamma$ in mouse splenocytes. Le Lait, November 2001, vol. 81 , no. 6 , p. 683-697.

CHAMPAGNE, C.P.; MORIN, N.; COUTURE, R.; GAGNON, C.; JELEN, P. and LACROIX, C. The potential of immobilized cell technology to produce freeze-dried, phage-protected cultures of Lactococcus lactis. Food Research International, 1992, vol. 25, no. 6, p. 419-427.

CHAMPAGNE, Claude P.; GIRARD, France and RODRIGUE, Natalie. Production of concentrated suspensions of thermophilic lactic acid bacteria in calciumalginate beads. International Dairy Journal, 1993, vol. 3, no. 3, p. 257-275.

CHAMPAGNE, C.P.; GAUDRAULT, H. and CONWAY, J. Effect of ultrafiltration of baker's and brewer's yeast extracts on their nitrogen content and turbidity. Acta Alimentaria, November 1999, vol. 28, no. 4, p. 321-328.

CHEIRSILP, Benjamas; SHIMIZU, Hiroshi and SHIOYA, Suteaka. Enhanced kefiran production by mixed culture of Lactobacillus kefiranofaciens and Saccharomyces cerevisiae. Journal of Biotechnology, January 2003, vol. 100 , no. 1 , p. 43-53.

DE VUYST, L.; VANDERVEKEN, F.; VAN DE VEN, S. and DEGEEST, B. Production by and isolation of exopolysaccharides from Streptococcus thermophilus grown in a milk medium and evidence for their grownassociated biosynthesis. Journal of Applied Microbiology, June 1998, vol. 84, no. 6, p. 1059-1068.

DE VUYST, Luc and DEGEEST, Bart. Heteropolysaccharide from lactic acid bacteria. FEMS 
Microbiology Reviews, April 1999, vol. 23, no. 2, p. 153177.

DE VUYST, Luc; DE VIN, Filip; VANINGELGEM, Frederik and DEGEEST, Bart. Recent developments in the biosynthesis and applications of heteropolysaccharides from lactic acid bacteria. International Dairy Journal, 2001, vol. 11, no. 9, p. 687-707.

DOLEYRES, Y. and LACROIX, C. Technologies with free and immobilised cells for probiotic bifidobacteria production and protection. International Dairy Journal, October 2005, vol. 15, no. 10, p. 973-988.

GAMAR-NOURANI, L.; BLONDEAU, K. and SIMONET, J.-M. Physiological approach to extracellular polysaccharide production by Lactobacillus rhamnosus strain C83. Journal of Applied Microbiology, August 1997, vol. 83 , no. 3, p. 281-287.

GAMAR-NOURANI, L.; BLONDEAU, K. and SIMONET, J.-M. Influence of culture conditions on exopolysaccharide production by Lactobacillus rhamnosus strain C83. Journal of Applied Microbiology, October 1998, vol. 85 , no. 4 , p. 664-672.

GASSEM, M.A.; SCHMIDT, K.A. and FRANK, J.F. Exopolysaccharide production in different media by lactic acid bacteria. Cultured Dairy Products Journal, 1995, vol. 30, p. 18-21.

GROBBEN, G.J.; SIKKEMA, J.; SMITH, M.R. and DE BONT, J.A.M. Production of extracellular polysaccharides by Lactobacillus delbrueckii ssp. bulgaricus NCFB 2772 grown in a chemically defined medium. Journal of Applied Bacteriology, 1995, vol. 79, no. 1, p. 103-107.

HOUTSMA, P.C.; DE WIT, J.C. and ROMBOUTS, F.M. Minimum inhibitory concentration (MIC) of sodium lactate and sodium chloride for spoilage organisms and pathogens at different $\mathrm{pH}$ values and temperatures. Journal of Food Protection, December 1996, vol. 59, no. 12, p. 1300-1304.

KORAKLI, Maher; PAVLOVIC, Melanie; GANZLE, Michael G. and VOGEL, Rudi F. Exopolysaccharide and kestose production by Lactobacillus sanfranciscensis LTH2590. Applied and Environmental Microbiology, April 2003, vol. 69, no. 4, p. 2073-2079.

LAMBOLEY, Laurence; ST-GELAIS, Daniel; CHAMPAGNE, Claude P. and LAMOUREUX, Maryse. Growth and morphology of thermophilic dairy starters in alginate beads. The Journal of General and Applied Microbiology, June 2003, vol. 49, no. 3, p. 205-214.

MACEDO, M.G.; LACROIX, C.; GARDNER, N.J. and CHAMPAGNE, C.P. Effect of medium supplementation on exopolysaccharide production by Lactobacillus rhamnosus RW-9595M in whey permeate. International Dairy Journal, 2002, vol. 12, no. 5, p. 419-426.
MORISHITA, Takashi; DEGUCHI, Yoriko; YAJIMA, Masako; SAKURAI, Toshizo and YURA, Takashi. Multiple nutritional requirements of lactobacilli: genetic lesions affecting amino acids biosynthesis pathways. Journal of Bacteriology, October 1981, vol. 148, no. 1, p. 64-71.

MOZZI, Fernanda; OLIVER, Guillermo; SAVOY DE GIORI, Graciela and FONT DE VALDEZ, Graciela. Influence of temperature on the production of exopolysaccharides by thermophilic lactic acid bacteria. Milchwissenschaft, 1995, vol. 50, no. 2, p. 80-82.

MOZZI, Fernanda; SAVOY DE GIORI, Graciela; OLIVER, Guillermo and FONT DE VALDEZ, Graciela. Exopolysaccharide production by Lactobacillus casei under controlled pH. Biotechnology Letters, April 1996a, vol. 18, no. 4, p. 435-439.

MOZZI, Fernanda; SAVOY DE GIORI, Graciela; OLIVER, Guillermo and FONT DE VALDEZ, Graciela. Exopolysaccharide production by Lactobacillus casei in milk under different growth conditions. Milchwissenschaft, 1996b, vol. 51, no. 12, p. 670-673.

PHAM, P.L.; DUPONT, I.; ROY, D.; LAPOINTE, G. and CERNING, J. Production of exopolysaccharide by Lactobacillus rhamnosus $\mathrm{R}$ and analysis of its enzymatic degradation during prolonged fermentation. Applied and Environmental Microbiology, June 2000, vol. 66, no. 6, p. 2302-2310.

PRASHER, R.; MALIK, R.K. and MATHUR, D.K. Utilization of whey for the production of extracellular polysaccharide by a selected strain of Lactococcus lactis. Microbiologie, Aliments, Nutrition, 1997, vol. 15, no. 1, p. 79-88.

RUAS-MADIEDO, Patricia; HUGENHOLTZ, Jeroen and ZOON, Pieternela. An overview of the functionality of exopolysaccharides produced by lactic acid bacteria. International Dairy Journal, 2002, vol. 12, no. 2-3, p. 163171.

RUAS-MADIEDO, Patricia; ALTING, Arno C. and ZOON, Pieternela. Effect of exopolysaccharides and proteolytic activity of Lactococcus lactis subsp. cremoris strains on the viscosity and structure of fermented milks. International Dairy Journal, February 2005, vol. 15, no. 2, p. $155-164$.

SHIHATA, A. and SHAH, N.P. Influence of addition of proteolytic strains of Lactobacillus delbrueckii subsp. bulgaricus to commercial ABT starter cultures on texture of yogurt, exopolysaccharide production and survival of bacteria. International Dairy Journal, 2002, vol. 12, no. 9, p. $765-772$.

STIEBER, R.W.; COULMAN, G.A. and GERHARDT, P. Dialysis continuous process for ammonium-lactate 


\section{Champagne, C.P. et al.}

fermentation of whey: Experimental tests. Applied and Environmental Microbiology, December 1977, vol. 34, no. 6, p. 733-739.

TORINO, M.I.; MOZZI, F.; SESMA, F. and FONT DE VALDEZ, G. Effect of stirring on growth and phosphopolysaccharide production by Lactobacillus helveticus ATCC 15807 in milk. Milchwissenschaft, 2000, vol. 55, no. 4, p. 204-207. 